\title{
Role of the clinical tutor
}

\section{J de Caestecker}

\section{Impending changes in organisation of postgraduate medical education risk loss of benefits of the clinical tutor}

T he clinical tutor function was established in the mid-1960s in parallel with provision of Exchequer funding for postgraduate education. Recognition of the need for educational facilities in district general hospitals resulted in the establishment of postgraduate medical centres, with educational programs developed and supervised by the clinical tutor. Since then the role of the clinical tutor has been more clearly defined both by the National Association of Clinical Tutors (which has informally published a draft generic job description for the clinical tutor $)^{1}$ and in the General Medical Council (GMC) documents The New Doctor $^{2}$ and The Early Years ${ }^{3}$ relating to pre-registration house officer and senior house officer training respectively. These roles are summarised in table 1.

Major policy changes such as those proposed in the government white paper A First Class Service have emphasised the central role of "life long learning" in the clinical governance framework, to "give NHS staff the tools of knowledge to offer the most modern, effective and high quality care to patients", and to "allow NHS staff to identify training needs across professions to aid clinical teamworking". ${ }^{4}$ Implicit in these proposals has been the desire to promote multidisciplinary learning opportunities, a direction exemplified by the subsuming of MADEL funding for postgraduate medical education into the budgets of the multidisciplinary workforce development confederations.

Some trusts, particularly in large cities, are amalgamating with neighbouring trusts and streamlining management. There will be pressure to look at management of delivery of education: clinical tutors may be asked to become involved in continuing education of consultant staff and might even be asked to manage education at more than one unit. Where does this leave the clinical

Table 1 Responsibilities of a clinical tutor ${ }^{1-3}$

\begin{tabular}{|c|c|}
\hline Responsibility & Detailed functions \\
\hline $\begin{array}{l}\text { Identify trainees' training needs } \\
\text { Ensure that education is provided }\end{array}$ & $\begin{array}{l}\text { - Induction of new doctors } \\
\text { - Formal pre-registration house officer } \\
\text { educational program } \\
\text { - Monitoring and/or provision of appraisal and } \\
\text { assessments for trainees (cooperate with } \\
\text { educational supervisors) } \\
\text { - Provide careers' advice and counselling } \\
\text { - Deal with welfare matters for trainees } \\
\text { - Approve/monitor trainee study leave } \\
\text { - Evaluate quality of education provision }\end{array}$ \\
\hline $\begin{array}{l}\text { Postgraduate centre management (with PGMC } \\
\text { manager) }\end{array}$ & $\begin{array}{l}\text { - Organise educational programs } \\
\text { - Management of postgraduate budget (library, } \\
\text { study leave) } \\
\text { - Chair local education committee } \\
\text { - Annual report and business plan } \\
\text { - Line management for PGMC manager }\end{array}$ \\
\hline Provide educational leadership & $\begin{array}{l}\text { - Liaise with others (college tutors, GP tutors, } \\
\text { nurse tutors) } \\
\text { - Liaise with trust management } \\
\text { - Recruitment and training of educational } \\
\text { supervisors (with postgraduate dean and } \\
\text { college tutors) } \\
\text { - Ensure fulfilment of postgraduate dean's } \\
\text { - Education and training contract } \\
\text { - Ensure delivery of university and Royal College } \\
\text { curricula (cooperate with college tutors) } \\
\text { - Participate in college and deanery visits and } \\
\text { - ensure high quality educational posts } \\
\text { - Mnvolvement in clinical governance } \\
\text { - Monitor library service provision }\end{array}$ \\
\hline
\end{tabular}

GP, general practitioner; PGMC, postgraduate medical centre.

tutor? The GMC documents make clear the lines of responsibility of the clinical tutor as the local representative of the postgraduate dean, providing a link between the university/postgraduate dean on the one hand and the NHS trust management on the other and coordinating effective delivery of the postgraduate educational contract.

The clinical tutor has traditionally been the trainee doctors' advocate, ensuring that posts have educational value, that formal educational time is protected, and that trainees have access to careers advice. To some extent this role is being taken on by nominated educational supervisors (distinct from clinical supervisors of specific training posts). Arguably, it will be to the detriment of junior doctor training if clinical tutors can no longer fulfil the role of advocate, especially if their responsibilities are split to include consultant appraisal and education. If the clinical tutor becomes effectively a trust employee it will make it difficult to be impartial with regard to issues such as protected time.

It is not inconceivable that postgraduate deans (who will now have to justify their budgets with the new workforce development confederations) may allow trusts to develop their own models of how to manage delivery of the postgraduate contract-which might not necessarily include the traditional clinical tutor role. For instance, there will be a temptation to appoint a "Director of Education" (who may or may not be a doctor and who may or may not have a seat on the trust executive board) to oversee multidisciplinary education within a trust. Who will then defend medical education? Clearly while it is laudable to encourage multidisciplinary educational opportunities where possible, much medical education cannot be delivered in this format. Oversight of postgraduate centres, particularly with regard to provision of attractive postgraduate meetings may suffer if a clinical tutor is not site-based but has rather to take responsibility for more than one unit.

Finally, most clinical tutor posts (but not all) attract one or two funded sessions: if it is proposed that the clinical tutor function includes consultant continuing education and appraisal, and particularly if an incumbent is asked to oversee more than one unit it may take up three or four sessions of time (which will need to be funded). Will the most motivated or able individuals wish to give up this much of their clinical sessions? These and the other questions need to be debated: change may be to the benefit of medical postgraduate education but we must be vigilant lest the benefits of a system that works well in many senses is lost irretrievably.

Postgrad Med J 2002;78:639-640 


\section{Author's affiliation}

Consultant Physician and Clinical Tutor, Glenfield Hospital, University Hospitals of Leicester NHS Trust, UK

Correspondence to: Dr de Caestecker; john.decaestecker@uhl-tr.nhs.uk

\section{REFERENCES}

1 National Association of Clinical Tutors Generic core job (postgraduate clinical tutor/director of PGME). November, 1999 (http://www.nact.org.uk/ point to "Documents" and then to "Generic Core Job Plan").

2 General Medical Council. The new doctor. London: GMC, April 1997 (http://www.gmc-uk.org/med ed/ meded frameset.htm)

3 General Medical Council. The early years. London: GMC, December 1998 (http://www.gmc-uk.org/med_ed/ meded frameset.htm).

4 Department of Health.. A first class service: quality in the new NHS. London: 1998 (http://www.doh.gov.uk/newnhs/quality.htm).

\section{A LIFE DEFINING MOMENT}

\section{Hospital experience as a patient}

eing in hospital for a life threatening condition is without doubt a significant event in a person's life.

$\mathbf{B}$ We doctors though, tend to forget that we are also vulnerable to such diseases. I was only 24 at the time, having just finished my final year elective attachment. Still recovering from a bad flu, I could hardly wait for the holidays to finish, as I had my job interviews straight after, followed by the last four months of my student life.

As soon as I went to bed a headache started building up. Within one hour I was screaming with pain and later on I started vomiting continuously. Two days later I was in intensive care with markedly reduced conscious level, and a heart rate of 30. I had massive cerebral oedema, which kept me in hospital for 32 days! During this very traumatic ordeal I experienced the humiliation of being washed by the nursing staff, fed by relatives, experiencing dysarthria, and suffering from delirium. Every day I could see the sadness, anguish, and fear in my friends' and relatives' faces. Every night I would start thinking about how close to death I had been, and most importantly what would happen to my life.

This adventure showed me exactly how patients feel when they are in our hands, and I believe this made me a much better doctor. The most important lesson I learned though was to enjoy life as much as I can, as it may end suddenly, without any warning.-Marios Tryfonidis, PRHO General Medicine, Manchester Royal Infirmary, UK; martryfonl@hotmail.com 